\title{
Hybrid Flexible Instruction: Exploring Faculty Preparedness
}

\author{
Enilda Romero-Hall \\ University of Tampa \\ Caldeira Ripine \\ University of Tampa
}

\begin{abstract}
The aim of this investigation was to survey faculty members on their perceived level of preparedness to design and implement hybrid flexible (HyFlex) instruction. Participants included 121 full- and part-time faculty. Using an electronic survey, faculty members: a) rated their preparedness to engage on different HyFlex instruction competencies, b) shared which pedagogical strategies they felt prepared to use in this instructional modality, and c) listed the resources and support that they felt were needed to successfully implement their course. The results indicated that faculty members felt prepared to successfully engage in competencies related to HyFlex instruction that were significantly similar to competencies required for in-person instruction. However, they admitted to feeling less prepared to manage the intricacies that are unique to the HyFlex modality. Also, instructors believe a variety of pedagogical strategies can be integrated into HyFlex instruction; however, for those unfamiliar with this instructional modality, significant support and resources are needed before designing and implementing a course.
\end{abstract}

Keywords: HyFlex, online learning, instructional modality, faculty, higher education

Romero-Hall, E., \& Ripine, C. (2021). Hybrid flexible instruction: Exploring faculty preparedness. Online Learning, 25(3), 289-312. doi: 10.24059/olj.v25i3.2426 
Hybrid Flexible instruction (HyFlex) refers to a combination of both online and face-toface instruction. It allows students who are unable to physically attend class sessions to be virtual attendees with real-time or asynchronous interactions with the instructor and their in-person classmates. As Irvine (2020) noted, "the specific characteristic here is that the learners have full control of their modality (face-to-face, online synchronous, or online asynchronous)."

Traditionally, learners who want to continue their education but are unable to attend an in-person course choose to pursue online education. However, research shows that the design of online instruction does have some faults; many online students endure some degree of loneliness without social interactions with other students (Chakraborty \& Victor, 2004). Various investigations report that online students also miss the engagement with professors through immediate feedback and one-on-one interactions, which traditional in-person courses typically have (Chakraborty \& Victor, 2004; Stewart et al., 2011; Park \& Bonk 2007).

Some institutions have started to explore the implementation of HyFlex instruction, in which students who are able to attend synchronous class sessions can participate virtually (Rogers et. al., 2003). HyFlex classrooms implement different educational technologies in which distance learners can interact with in-person students and communicate with the instructor in real time (Roseth et al., 2013) as well as in fully online, asynchronous formats. The implementation of HyFlex instruction was initially driven by universities with limited physical space that wished to accommodate more learners, and by institutions wanting to give access to learners with educational needs who are unable to relocate or physically attend a classroom. More recently, the desire to implement HyFlex instruction has been driven by the social distancing guidelines that educational institutions must follow to diminish the spread of the SARS-CoV-2 virus while ensuring continuity of education during this pandemic.

It is important to note that HyFlex instruction is novel and experimental. Yet, a similar instructional modality with different technological configurations has been used in the past. In the 1990s, The Georgia State Academic and Medical System (GSAMS) was used by the University System of Georgia to allow live, interactive, two-way video conferencing between as many as 16 sites during individual conferences (Gruenhagen et al., 1999). The distance education system GSAMS served to connect a teacher preparation program to student teachers in rural areas. While many lessons can be learned from these early distance education efforts, the GSAMS multiway television broadcast courses and HyFlex instruction are not the exact same modality. Therefore, researchers today need to continue to investigate how universities can prepare faculty members if they decide to design, develop, and implement HyFlex instruction. While many researchers have studied the implementation of this type of instruction (Bell et al., 2014; Chakraborty \& Victor, 2004; Moore et al., 2017; Park \& Bonk, 2007; Popov, 2009; Roseth et al., 2013; Ryu \& Boggs, 2016; Stewart et al., 2011; Szeto, 2015), little research exists examining faculty preparedness regarding HyFlex teaching and learning.

The aim of this study was to survey full- and part-time faculty at an institution of higher education on their preparedness for the implementation of HyFlex instruction. The results support an understanding of faculty readiness for this mode of instruction, the pedagogical strategies they believe are best suited for this instructional format, and the support and resources needed to successfully implement this type of learning experience. 


\section{Purpose Statement and Research Questions}

The aim of this investigation was to survey faculty members about their level of preparedness to use HyFlex instruction. It is critical to investigate how faculty members perceive HyFlex instruction, what pedagogical strategies they feel are best suited for this instructional format, and what support and resources are needed, from their standpoint, to successfully implement this instructional format. Data for this investigation were collected prior to the COVID-19 pandemic. When the World Health Organization declared COVID-19 a pandemic, educational institutions had to pivot into emergency remote instruction and then make plans for instructional continuity. The results of this investigation are critical because many of these instructional continuity plans now involve the implementation of HyFlex. The research questions that guided this investigation are the following:

RQ1: What are faculty perceptions of their preparedness towards teaching using HyFlex learning experiences?

RQ2: What pedagogical strategies do faculty members feel are best suited for HyFlex learning experiences?

RQ3: What resources and support do faculty members feel are needed to successfully implement HyFlex learning experiences?

\section{Literature Review}

Educational institutions have aimed to implement pedagogy and technology to best adapt to the current world and equip learners with 21st-century skills. Additionally, educational institutions are working toward providing learners with access to learning experiences regardless of their geographical location. This access to education has taken place in the form of various online, hybrid, and blended learning instructional formats (Irvine, 2020). As previously mentioned, one type of online distance education format that institutions are starting to explore and implement is HyFlex instruction. Our review of the literature identifies some of the most recent research efforts that address a) HyFlex instruction and b) blended synchronous learning with HyFlex elements embedded.

Stewart et al. (2011) investigated the implementation of HyFlex instruction with 18 graduate college students working towards a doctorate in education. Fourteen students physically attended the classes while the four others virtually joined through a video conferencing program from an external site. The researchers observed the classes and provided open-ended surveys over a two-year period. Through survey responses, the learners did not report a change in participation levels but did note an increased difficulty with non-verbal communication in class. Wang et al. (2017) also studied the gradual implementation of a blended synchronous learning environment with the capability of supporting online and in-person students simultaneously. The researchers surveyed graduate students after each of the four rounds of implementation of blended synchronous learning. The surveys demonstrated that the graduate students responded positively to the blended synchronous learning environment; however, several design principles had to be considered, including the design of activities to be more inclusive of the remote learners, a partnership strategy to increase attention and communication between the instructor and all the learners, pre-training on the learning environment to reduce technical difficulties, and clear video communication (Wang et al., 2017). 
The results of other investigations also raised awareness of issues related to communication between the instructor and the students when implementing HyFlex instruction. Moore et al. (2017) implemented a four-course professional development series for pre-service teachers on blended classrooms and underwent evaluation cycles: pre-course, pilot course, and the ongoing actual course. Results of the evaluation showed that the communication and interactions among all students were rated with the highest satisfaction whereas the instructor's evaluation and support were rated with the lowest satisfaction scores. Rogers et al. (2003) also focused on better understanding the instructors' and students' experiences after transitioning to blended synchronous classrooms. Like Moore et al. (2017), the results indicated that instructors faced challenges with the adaptation to instructions for distance students. Distance students felt alienated due to technical difficulties where they missed comments made in the in-person classroom without the ability to playback. In a case study by Park and Bonk (2007) on synchronous multi-media, researchers emphasized how learning was promoted with the mediated interaction among online learners, in-person learners, and the instructor. Despite technical difficulties, students reported many effective components, including team-teaching capabilities, multiple multimedia tools, and new experiences. Another case study was conducted by RomeroHall and Vicentini (2017) in which three graduate students in an instructional design and technology program participated as online learners in HyFlex instruction during two consecutives semesters while in their master level program. The results of that case revealed that lack of adequate technological infrastructure led to challenges related to interactions and communications with in-person classmates and feelings of inequality in the course (i.e., during group project distance learners did not feel treated equally by in-person classmates). However, the case study also highlighted the importance of instructor proactive actions to maintain open communication channels with all learners, make material available prior to instruction, and ensure equity in class activities and assessments.

According to several research findings, the acceptance of HyFlex modality in terms of effective design and implementation for instruction varies greatly. Popov (2009) investigated several negative points of view towards HyFlex instruction, expressed by the participants (graduate students and lecturers in a master level program). According to Popov (2009), the graduate students and lecturers emphasized many challenging aspects, including poor communication among students and teachers, distracting technology, lack of structure for assignments, and assessment differences that benefitted online learners over in-person learners. Overall, the graduate students and lecturers who participated in this study did not find HyFlex instruction effective. Similarly, Chakraborty and Victor (2004) conducted a case study related to HyFlex instruction that included face-to-face and remote learners. The researchers discovered that the main issues were technical difficulties which made the course more difficult for remote learners (Chakraborty \& Victor, 2004). Bourdeau et al., (2018) compared in-person, online, and HyFlex learning with a focus on academic success rates, concluding that in-person learning had fewer failures than online learning, which had fewer failures than HyFlex learning.

Some research has emphasized how HyFlex instruction relies on the context of the situations and setting. For example, Bell et al. (2014) aimed to find the most efficient integration between technology and instruction in multiple locations using different formats such as linked classes, shared portals, personal portals, and small groups. The researchers concluded that the effectiveness in one setting during a specific semester could not predict the effectiveness in other settings in a different semester because the conditions called for customization using different formats (i.e., linked classes, shared portals, personal portals, and small groups). 
Szeto (2015) focused on the instructional effects of the community of inquiry (teaching, social, and cognitive presence) in blended synchronous teaching and learning with first-year engineering students. Szeto (2015) concluded that teaching presence had more effect than social and cognitive presence in this particular context, as teaching presence made a bigger impact on the assessment scores of the learner. Additionally, the researcher noted that teaching presence varied during class sessions. For example, during discussions, moments of confusion arose due to the novel challenge of connecting with the online students via a screen. The results indicated that social presence thrived in instances where students had to rely more on visual and audio cues to communicate with their virtual peers. Finally, Angelone et al. (2020) used a case study approach to determine the technological design of a blended synchronous environment for a graduate level course designed as here or there (HoT). The aim was to explore how the technological design of blended synchronous learning environments influenced the learner experience. Using an iterative and contextual process, the study revealed that, the integration of only the technology deemed necessary to support pedagogy and create co-presence between and among learners was critical to create more seamless experiences. Angelone, et al. (2020) also determined that co-presence can be enhanced using visual and physical connections and inclusive language.

\section{Participants}

\section{Methods}

Permission was obtained from the Office of Institutional Research to email all full- and part-time faculty members teaching at a university in Southeastern United States. A total of 1,002 faculty members were invited to participate in the survey via a formal email sent by the principal investigator. The email specified the name and contact information of the principal investigator, the purpose of the research project, confidentiality information, and details of participation. Faculty members were asked to provide consent before proceeding with the electronic survey. Representing a response rate of 12.07\%, 121 individuals consented to participate in this investigation. Participants were 18 years and older.

Demographics. The results for the demographic information of the participants' gender showed that the majority self-identified as females (see Fig. 1).

\section{Figure 1}

Percentage of Participants Per Self-Reported Gender

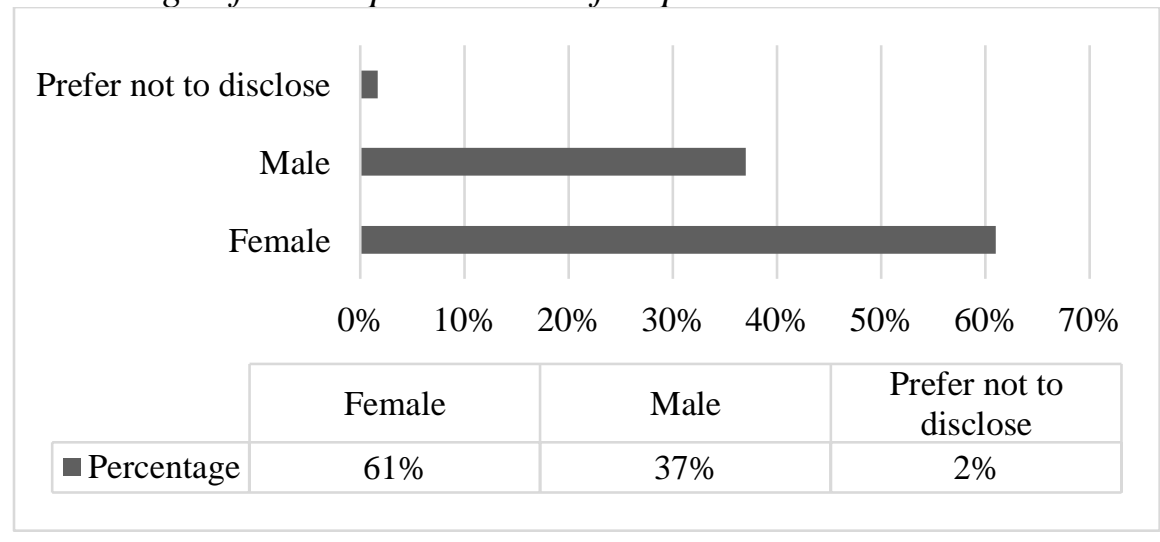


However, some participants self-identified as males and only a small percentage of participants preferred not to disclose their gender. Also, most participants identified as non-tenure track, but tenured and tenure track faculty members also consented to participate (see Fig. 2).

Figure 2

Percentage of Participants per Self-Reported Academic Rank

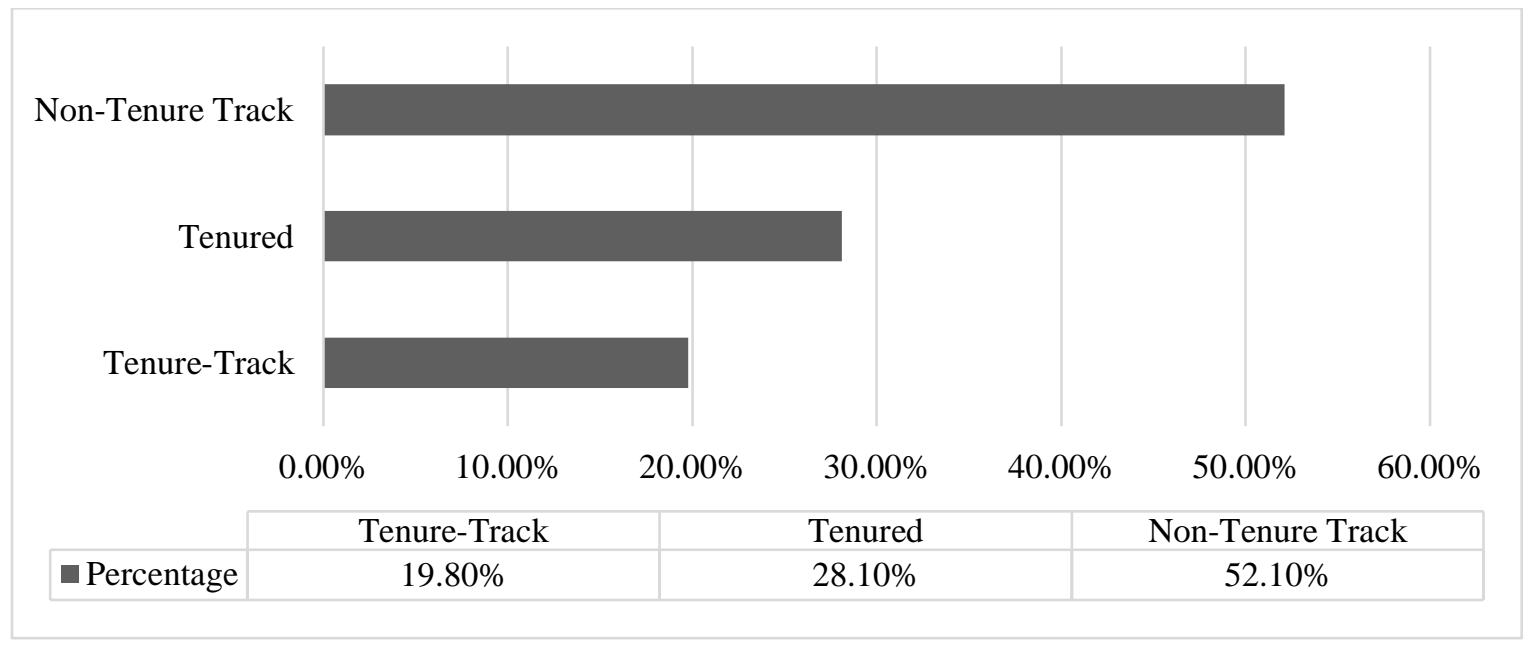

Participants were also asked to self-report their total a) years of teaching experience, b) years of teaching experience in an online environment, and c) years of teaching experience in a HyFlex environment. A cross-tabulation analysis based on the participants' self-reported college affiliation within the institution and years of teaching experience in different instructional formats is shown in Table 1.

\section{Table 1}

Cross-Tabulation Analysis based on the Participants' Self-Reported College Affiliation Within the Institution and Years of Teaching Experience in Different Instructional Formats

\begin{tabular}{llcccc}
\hline & $\begin{array}{c}\text { College of } \\
\text { Arts and } \\
\text { Letters }\end{array}$ & $\begin{array}{c}\text { College Affiliation at the Institution } \\
\text { College of Health } \\
\text { and Natural } \\
\text { Sciences }\end{array}$ & $\begin{array}{c}\text { College of Social Science, } \\
\text { Mathematics, and } \\
\text { Education }\end{array}$ & $\begin{array}{c}\text { College } \\
\text { of } \\
\text { Business }\end{array}$ \\
\hline $\begin{array}{l}\text { Years of } \\
\text { teaching } \\
\text { experience }\end{array}$ & $\begin{array}{l}\text { 0 to less than 1 } \\
\text { year }\end{array}$ & $2.8 \%$ & $0.0 \%$ & $0.0 \%$ & $0.0 \%$ \\
& 1 to 5 years & $8.3 \%$ & $30.8 \%$ & $25.8 \%$ & $7.1 \%$ \\
& 11 to 15 years & $22.2 \%$ & $23.1 \%$ & $9.7 \%$ & $14.3 \%$ \\
& $\begin{array}{l}\text { 6 to 10 years } \\
\text { More than 15 }\end{array}$ & $27.8 \%$ & $15.4 \%$ & $16.1 \%$ & $32.1 \%$ \\
& $38.9 \%$ & $23.1 \%$ & $45.2 \%$ & $46.4 \%$ \\
& $\begin{array}{l}\text { years } \\
\text { year }\end{array}$ & $41.7 \%$ & $30.8 \%$ & $58.1 \%$ & $46.4 \%$
\end{tabular}




\begin{tabular}{|c|c|c|c|c|c|}
\hline \multirow{4}{*}{$\begin{array}{l}\text { Years of } \\
\text { teaching in an } \\
\text { online format }\end{array}$} & 1 to 5 years & $33.3 \%$ & $50.0 \%$ & $22.6 \%$ & $39.3 \%$ \\
\hline & 11 to 15 years & $2.8 \%$ & $0.0 \%$ & $0.0 \%$ & $0.0 \%$ \\
\hline & 6 to 10 years & $16.7 \%$ & $11.5 \%$ & $12.9 \%$ & $10.7 \%$ \\
\hline & $\begin{array}{l}\text { More than } 15 \\
\text { years }\end{array}$ & $5.6 \%$ & $0.0 \%$ & $3.2 \%$ & $3.6 \%$ \\
\hline \multirow{5}{*}{$\begin{array}{l}\text { Years of } \\
\text { teaching in a } \\
\text { HyFlex format }\end{array}$} & $\begin{array}{l}0 \text { to less than } 1 \\
\text { year }\end{array}$ & $63.9 \%$ & $65.4 \%$ & $77.4 \%$ & $67.9 \%$ \\
\hline & 1 to 5 years & $25.0 \%$ & $23.1 \%$ & $19.4 \%$ & $25.0 \%$ \\
\hline & 11 to 15 years & $0.0 \%$ & $0.0 \%$ & $0.0 \%$ & $0.0 \%$ \\
\hline & 6 to 10 years & $8.3 \%$ & $3.8 \%$ & $0.0 \%$ & $7.1 \%$ \\
\hline & $\begin{array}{l}\text { More than } 15 \\
\text { years }\end{array}$ & $2.8 \%$ & $0.0 \%$ & $0.0 \%$ & $0.0 \%$ \\
\hline
\end{tabular}

The demographic results illustrate the participants' self-reported exposure to training related to distance learning (see Fig. 3).

Figure 3

Participants' Self-reported Exposure to Training Related to Distance Learning

\section{Electronic Survey}

Data were collected via an electronic survey with closed and open-ended questions using Qualtrics. The questionnaire included inquiries related to the participants': a) demographic, b) preparedness for HyFlex instruction, c) pedagogical strategies that they feel are best suited for HyFlex instruction, and d) support and resources needed at their institution to successfully implement this type of learning experiences. The electronic survey was adapted from the validated instrument Faculty Readiness to Teach Online (FRTO) developed by Martin, Budhrani $\&$ Wang (2020). Certain items related to course design, course communication, time management, and technical competence that related to HyFlex instruction were adapted and used as part of the electronic survey for this investigation (see Appendix A). 


\section{Data Analysis}

For RQ1, descriptive statistics are reported at the item level. For RQ2 and RQ3, the researchers employed a qualitative, iterative, and process-oriented team coding approach. Two researchers conducted open coding focused on identifying patterns and clusters across the responses provided by the participants (Creswell, 2009). Specifically, the analysis of RQ2 and RQ3 used the coding process approach by Tesch (1990) which was as follows:

1. All responses that addressed the research questions were read.

2. An initial coding of the first 35 responses were clustered into similar topics (these topics were formed into columns in a spreadsheet with major topics, unique topics, and leftovers).

3. The researchers engaged in discussion and peer checking and came to agreement.

4. The research went back to the data, abbreviated topics into codes, and wrote codes next to the appropriate segment responses provided by the participants.

5. A recoding of the initial 35 responses was conducted.

6. The researchers again engaged in discussion to reduce the total list of categories by grouping topics that related to each other and final decisions on the codes were made.

7. Already coded data was recoded, and remaining data were coded.

To further enhance the rigor of the study and analysis, the researchers actively engaged in a reflective process in which we constantly located ourselves and our analysis in relation to our own lived experience, positionality, and epistemology.

\section{Results}

Although 121 individuals consented to participate in this investigation, the results are based on $n=107$ completed surveys. Surveys with fewer than 80 percent of the items completed were dismissed from the analysis for the following research questions.

\section{RQ1. What are faculty perceptions of their preparedness towards teaching using HyFlex learning experiences?}

Participants were asked to assess their preparedness toward teaching using HyFlex learning experiences by reflecting and evaluating 11 competency statements presented in the survey. The rating used to evaluate their level of preparedness was the following: "I can do it very well," "I can do it," or "I cannot do it."

The results of the survey indicated that faculty members felt they were very well prepared to communicate course goals and outcomes at the beginning of the course, for both in-person and online students $(n=73)$; communicate as needed with in-person and online students about course progress and changes via email, course announcements, and others $(n=69)$; encourage a safe, inviting, and mutually respectful HyFlex environment by communicating with students in a positive tone and by promoting Netiquette guidelines $(n=62)$; establish a presence, for both inperson and online students, on a regular basis via course announcements, assignments, emails, online office hours, and various other methods $(n=61)$; and respond to in-person and online students' inquiries via email or phone within 12 - 24 hours to guide students towards a positive learning outcome $(n=55)$.

Additionally, faculty members felt moderately prepared to attend to the unique challenges of distance learning where learners are separated by time and geographic proximity $(n=56)$; attend to learning needs and situations of both traditional age and adult learners and provide a HyFlex educational experience that is appropriate for both $(n=55)$; achieve mastery of the teaching and learning in a HyFlex environment by becoming familiar with all materials, tools, 
and organization of the course environment $(n=55)$; demonstrate sensitivity to disabilities and diversities throughout the synchronous online course, including aspects of cultural, cognitive, emotional, and physical differences $(n=54)$; and monitor and manage in-person and online student progress by using course statistics or reports to identify students who are not accessing course materials or participating in learning activities and reach out to encourage engagement $(n=49)$.

Overall, participants did not overwhelmingly respond "I cannot do it" to any of the competency statements regarding their preparedness towards teaching using HyFlex learning (as shown in Table 2). For all the competency statements, the "I cannot do it" ratings were less than 14.95 percent.

\section{Table 2}

\section{Faculty Preparedness Towards Teaching Using HyFlex Learning Experiences}

\begin{tabular}{|c|c|c|c|}
\hline \multirow[t]{2}{*}{ Survey Items } & \multicolumn{3}{|c|}{ Responses } \\
\hline & I cannot do it & I can do it & $\begin{array}{l}\text { I can do it very } \\
\text { well }\end{array}$ \\
\hline $\begin{array}{l}\text { Attend to the unique challenges of distance } \\
\text { learning where learners are separated by time and } \\
\text { geographic proximity. }\end{array}$ & $\begin{array}{l}11.21 \% \\
\mathrm{n}=12\end{array}$ & $\begin{array}{l}52.34 \% \\
\mathrm{n}=56\end{array}$ & $\begin{array}{c}36.45 \% \\
n=39\end{array}$ \\
\hline $\begin{array}{l}\text { Attend to learning needs and situations of both } \\
\text { traditional age and adult learners, providing a } \\
\text { synchronous online educational experience that is } \\
\text { appropriate for both. }\end{array}$ & $\begin{array}{c}14.95 \% \\
n=16\end{array}$ & $\begin{array}{l}51.40 \% \\
\mathrm{n}=55\end{array}$ & $\begin{array}{c}33.64 \% \\
\mathrm{n}=36\end{array}$ \\
\hline $\begin{array}{l}\text { Achieve mastery of the teaching and learning in a } \\
\text { synchronous online environment by becoming } \\
\text { familiar with all materials, tools, and organization } \\
\text { of the course environment. }\end{array}$ & $\begin{array}{c}14.02 \% \\
\mathrm{n}=15\end{array}$ & $\begin{array}{c}51.40 \% \\
\mathrm{n}=55\end{array}$ & $\begin{array}{c}34.58 \% \\
\mathrm{n}=37\end{array}$ \\
\hline $\begin{array}{l}\text { Respond to in-person and online students' inquiries } \\
\text { via email or phone within } 12 \text { - } 24 \text { hours to guide } \\
\text { students towards a positive learning outcome. }\end{array}$ & $\begin{array}{c}8.41 \% \\
n=9\end{array}$ & $\begin{array}{c}40.19 \% \\
n=43\end{array}$ & $\begin{array}{c}51.40 \% \\
\mathrm{n}=55\end{array}$ \\
\hline $\begin{array}{l}\text { Provide detailed feedback on assignments and } \\
\text { exams, in synchronous online format, through } \\
\text { facilitation, guidance, directed learning, and } \\
\text { progress assessment. }\end{array}$ & $\begin{array}{l}11.21 \% \\
\mathrm{n}=12\end{array}$ & $\begin{array}{c}40.19 \% \\
n=43\end{array}$ & $\begin{array}{l}48.60 \% \\
n=52\end{array}$ \\
\hline $\begin{array}{l}\text { Communicate as needed with in-person and online } \\
\text { students about course progress and changes via } \\
\text { email, course announcements, etc. }\end{array}$ & $\begin{array}{c}2.80 \% \\
\mathrm{n}=3\end{array}$ & $\begin{array}{c}32.71 \% \\
\mathrm{n}=35\end{array}$ & $\begin{array}{c}64.49 \% \\
\mathrm{n}=69\end{array}$ \\
\hline $\begin{array}{l}\text { Encourage a safe, inviting, and mutually } \\
\text { respectful synchronous online environment by }\end{array}$ & $\begin{array}{c}3.74 \% \\
n=4\end{array}$ & $\begin{array}{c}38.32 \% \\
n=41\end{array}$ & $\begin{array}{c}57.94 \% \\
n=62\end{array}$ \\
\hline
\end{tabular}




\begin{tabular}{|c|c|c|c|}
\hline $\begin{array}{l}\text { Monitor and manage in-person and online student } \\
\text { progress by using course statistics or reports to } \\
\text { identify students who are not accessing course } \\
\text { materials or participating in learning activities and } \\
\text { reach out to encourage engagement. }\end{array}$ & $\begin{array}{c}11.21 \% \\
\mathrm{n}=12\end{array}$ & $\begin{array}{c}45.79 \% \\
\mathrm{n}=49\end{array}$ & $\begin{array}{c}42.99 \% \\
\mathrm{n}=46\end{array}$ \\
\hline $\begin{array}{l}\text { Communicate course goals and outcomes using the } \\
\text { syllabus and course announcements at the } \\
\text { beginning of the course, for both in-person and } \\
\text { online students. }\end{array}$ & $\begin{array}{c}5.61 \% \\
\mathrm{n}=6\end{array}$ & $\begin{array}{c}26.17 \% \\
\mathrm{n}=28\end{array}$ & $\begin{array}{c}68.22 \% \\
n=73\end{array}$ \\
\hline $\begin{array}{l}\text { Establish my presence, for both in-person and } \\
\text { online students, on a regular basis via course } \\
\text { announcements, assignments, emails, online office } \\
\text { hours, and various other methods. }\end{array}$ & $\begin{array}{c}5.61 \% \\
\mathrm{n}=6\end{array}$ & $\begin{array}{c}37.38 \% \\
\mathrm{n}=40\end{array}$ & $\begin{array}{c}57.01 \% \\
\mathrm{n}=61\end{array}$ \\
\hline $\begin{array}{l}\text { Throughout the synchronous online course, } \\
\text { demonstrate sensitivity to disabilities and } \\
\text { diversities, including aspects of cultural, cognitive, } \\
\text { emotional, and physical differences. }\end{array}$ & $\begin{array}{c}13.08 \% \\
\mathrm{n}=14\end{array}$ & $\begin{array}{c}50.47 \% \\
\mathrm{n}=54\end{array}$ & $\begin{array}{c}36.45 \% \\
n=39\end{array}$ \\
\hline
\end{tabular}

A cross-tabulation analysis was also conducted to gain a sense of how faculty members rated their preparedness towards teaching using HyFlex learning experiences, while also understanding whether they have prior formal training related to the design, development, and/or implementation of Internet-based distance education (see Table 3). The results indicate that, overall, faculty members who felt well prepared to address the various HyFlex competencies had had some sort of formal training on Internet-based distance education. The results indicate the exact opposite for those who felt unprepared to implement these HyFlex competencies. A high percentage of participants who felt unprepared to implement these HyFlex competencies reported that they have not received training on Internet-based distance education.

Table 3

Crosstabulation of Faculty Preparedness Towards Teaching Using HyFlex Based on Prior Formal Training on Internet-based Distance Education

\begin{tabular}{|c|c|c|c|c|}
\hline \multirow[t]{2}{*}{ Statements } & \multirow[t]{2}{*}{$\begin{array}{l}\text { Level of } \\
\text { Preparedness }\end{array}$} & \multicolumn{3}{|c|}{$\begin{array}{l}\text { Have you received any formal } \\
\text { training related to the designing, } \\
\text { developing, and/or implementing } \\
\text { Internet-based distance education? }\end{array}$} \\
\hline & & Total & No & Yes \\
\hline \multirow{3}{*}{$\begin{array}{l}\text { Attend to the unique challenges } \\
\text { of distance learning where } \\
\text { learners are separated by time } \\
\text { and geographic proximity. }\end{array}$} & I can do it very well & $33.1 \%$ & $14.3 \%$ & $50.0 \%$ \\
\hline & I can do it & $47.5 \%$ & $55.4 \%$ & $40.3 \%$ \\
\hline & I cannot do it & $10.2 \%$ & $17.9 \%$ & $3.2 \%$ \\
\hline \multirow{4}{*}{$\begin{array}{l}\text { Attend to learning needs and situations of both } \\
\text { traditional age and adult learners, providing a } \\
\text { synchronous online educational experience that } \\
\text { is appropriate for both. }\end{array}$} & I can do it very well & $30.5 \%$ & $12.5 \%$ & $46.8 \%$ \\
\hline & I can do it & $46.6 \%$ & $58.9 \%$ & $35.5 \%$ \\
\hline & I cannot do it & $13.6 \%$ & $16.1 \%$ & $11.3 \%$ \\
\hline & I can do it very well & $31.4 \%$ & $17.9 \%$ & $43.5 \%$ \\
\hline
\end{tabular}


Achieve mastery of the teaching and learning in a synchronous online environment by becoming familiar with all materials, tools, and organization of the course environment.

Respond to in-person and online student's inquiries via email or phone within 12 - 24 hours to guide students towards a positive learning outcome.

Provide detailed feedback on assignments and exams, in synchronous online format, through facilitation, guidance, directed learning, and progress assessment.

Communicate as needed with in-person and online students about course progress and changes via email, course announcements, etc.

Encourage a safe, inviting, and mutually respectful synchronous online environment by communicating with students in a positive tone and by promoting Netiquette guidelines.

Monitor and manage in-person and online student progress by using course statistics or reports to identify students who are not accessing course materials or participating in learning activities and reach out to encourage engagement.

Communicate course goals and outcomes using the syllabus and course announcements at the beginning of the course, for both in-person and online students).

Establish my presence, for both in-person and online students, on a regular basis via course announcements, assignments, emails, online office hours, and various other methods.

Throughout the synchronous online course, demonstrate sensitivity to disabilities and diversities, including aspects of cultural, cognitive, emotional, and physical differences.
I can do it
$46.6 \%$
$55.4 \%$
$38.7 \%$
I cannot do it
$12.7 \%$
$14.3 \%$
$11.3 \%$

\begin{tabular}{llll} 
I can do it very well & $46.6 \%$ & $37.5 \%$ & $54.8 \%$ \\
I can do it & $36.4 \%$ & $39.3 \%$ & $33.9 \%$ \\
I cannot do it & $7.6 \%$ & $10.7 \%$ & $4.8 \%$ \\
I can do it very well & $44.1 \%$ & $25.0 \%$ & $61.3 \%$ \\
I can do it & $36.4 \%$ & $50.0 \%$ & $24.2 \%$ \\
I cannot do it & $10.2 \%$ & $12.5 \%$ & $8.1 \%$ \\
& & & \\
I can do it very well & $58.5 \%$ & $44.6 \%$ & $71.0 \%$ \\
I can do it & $29.7 \%$ & $39.3 \%$ & $21.0 \%$ \\
I cannot do it & $2.5 \%$ & $3.6 \%$ & $1.6 \%$ \\
I can do it very well & $52.5 \%$ & $39.3 \%$ & $64.5 \%$ \\
I can do it & $34.7 \%$ & $44.6 \%$ & $25.8 \%$ \\
I cannot do it & $3.4 \%$ & $3.6 \%$ & $3.2 \%$ \\
\hline I can do it very well & $39.0 \%$ & $30.4 \%$ & $46.8 \%$ \\
I can do it & $41.5 \%$ & $41.1 \%$ & $41.9 \%$ \\
I cannot do it & $10.2 \%$ & $16.1 \%$ & $4.8 \%$
\end{tabular}

I can do it very well

I can do it

I cannot do it

I can do it very well

I can do it

I cannot do it

I can do it very well

I can do it

I cannot do it
$61.9 \%$

$23.7 \%$

$5.1 \%$

$41.1 \%$

$80.6 \%$

$37.5 \% \quad 11.3 \%$

$8.9 \%$

$1.6 \%$

$51.7 \%$

$39.3 \%$

$62.9 \%$

$33.9 \%$

$39.3 \%$

$29.0 \%$

$5.1 \%$

$8.9 \%$

$1.6 \%$

$33.1 \%$

$25.0 \%$

$40.3 \%$

$45.8 \%$

$48.2 \%$

$43.5 \%$

$11.9 \%$

$14.3 \%$

$9.7 \%$

\section{RQ2. What pedagogical strategies do faculty feel are best suited for HyFlex learning experiences?}

Using an open-ended question, participants were asked to share which pedagogical strategies they felt were best suited for HyFlex learning at their institution (see Table 4). Many responses $(n=21)$ to this open-ended question specified that faculty members were unsure of pedagogical strategies that could be implemented because they were unfamiliar with HyFlex teaching and learning. Those who were familiar with HyFlex learning stated that if given the option to teach in this format, they would integrate various pedagogical strategies such as 
synchronous video sessions $(n=17)$, online discussion boards $(n=15)$, interactive activities $(n=14)$ with students (i.e., breakout rooms), learner-centered strategies $(n=11)$ such as adult learning theories, inquiry-based approaches $(n=9)$ such as case studies, pre-recorded videos and lectures $(n=9)$, and content sharing via the learning management system $(n=9)$.

\section{Table 4}

HyFlex Pedagogical Strategies, Percentages of Contributed Statements, and Representative Comments by Faculty Members

\section{$\begin{array}{lll}\text { Pedagogical Strategies } & \text { Percentage } & \text { Example Statements }\end{array}$}

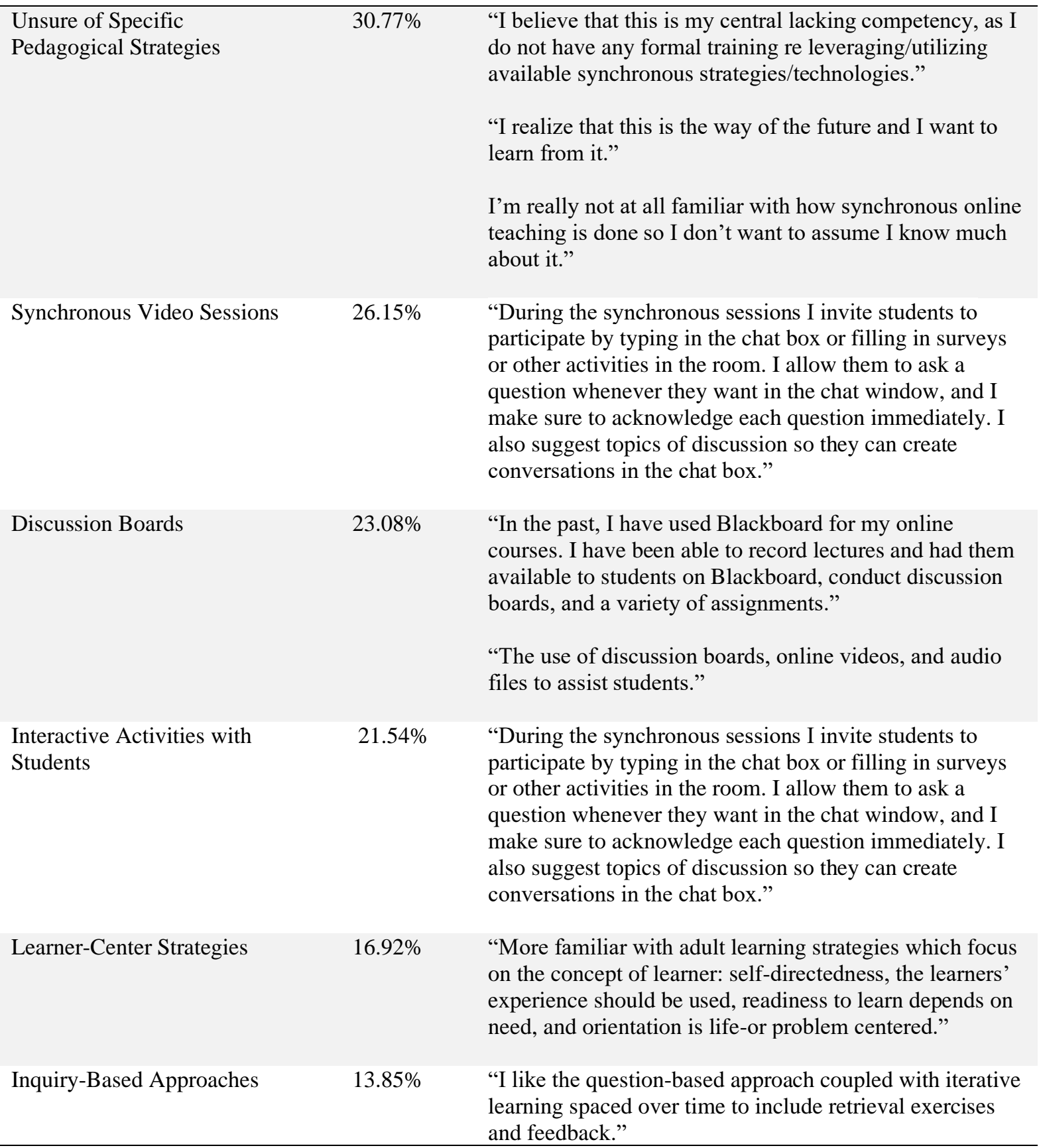




\begin{tabular}{|c|c|c|}
\hline Online Videos & $13.85 \%$ & $\begin{array}{l}\text { "Video-based apps and formats that encourage a different } \\
\text { way to respond and engage in dialogue." } \\
\text { "Record lecture and hold virtual office hours." }\end{array}$ \\
\hline $\begin{array}{l}\text { Content Sharing via the } \\
\text { Learning Management } \\
\text { System }\end{array}$ & $13.85 \%$ & $\begin{array}{l}\text { "Proficiency with LMS and various tools that allow for } \\
\text { small group and whole group instruction, breakout } \\
\text { sessions, and I find that real time whiteboards and } \\
\text { collaborative writing tools are useful for online teaching." }\end{array}$ \\
\hline Live Collaboration & $9.23 \%$ & $\begin{array}{l}\text { "I use a good deal of social constructivism in my classes } \\
\text { to engagement my learners and it with synchronous } \\
\text { online teaching encouraging the use of webinar rooms, } \\
\text { live spreadsheets, and documents." }\end{array}$ \\
\hline $\begin{array}{l}\text { Nurturing and Mentoring of } \\
\text { Students' Growth }\end{array}$ & $9.23 \%$ & $\begin{array}{l}\text { "Once a student has identified as ready for synchronous } \\
\text { learning, I gear up to meet the individuals' motivations. } \\
\text { The intrinsic motivation is present, my strategy is to } \\
\text { nurture and encourage the student to remain motivated." }\end{array}$ \\
\hline Email Communication & $7.69 \%$ & $\begin{array}{l}\text { "These [math] problems will be 'turned in' via email." } \\
\text { "I try to respond to email as much as possible." }\end{array}$ \\
\hline $\begin{array}{l}\text { Asynchronous Online } \\
\text { Strategies }\end{array}$ & $6.15 \%$ & $\begin{array}{l}\text { "I employ multiple strategies that incorporate } \\
\text { synchronous, asynchronous and conventional online } \\
\text { pedagogy that engages students on multiple platforms." }\end{array}$ \\
\hline Virtual Testing & $6.15 \%$ & $\begin{array}{l}\text { I will be using my math lab as a homework tool to allow } \\
\text { student to handle more complex problems by themselves. } \\
\text { I am going to use recorded lecture with an 'in class' } \\
\text { practice portion. These problems will be turned in via } \\
\text { email. I plan to use proctoring software for the security of } \\
\text { tests. I also am planning virtual office hours." }\end{array}$ \\
\hline Backwards Design Approach & $3.08 \%$ & $\begin{array}{l}\text { "Starting with the end in mind and working backward, } \\
\text { using deliberate activities and exercises that introduce and } \\
\text { reinforce learning objectives." }\end{array}$ \\
\hline Teacher-Focused Strategies & $1.54 \%$ & "Teacher-centered, content-focused, and participatory." \\
\hline
\end{tabular}

Participants mentioned other pedagogical approaches but with less frequency. These pedagogical approaches include the use of live collaboration $(n=6)$ to work on documents or spreadsheets, the nurturing or mentoring of students' growth $(n=6)$ at a more individual level, increased email communication $(n=5)$, using asynchronous online strategies $(n=4)$, virtual testing $(n=4)$, backward design $(n=2)$, and teacher-focused strategies $(n=1)$.

\section{RQ3. What resources and support do faculty feel are needed to successfully implement HyFlex learning experiences?}


Using an open-ended question, faculty members were asked to state which resources they felt were needed to successfully implement HyFlex learning opportunities at their institution. Analysis of responses $(n=69)$ to this open-ended question revealed that an array of resources were deemed necessary. Some of the most often mentioned resources include synchronous and asynchronous software $(n=19)$, video equipment in the in-person classrooms $(n=16)$, reliable equipment for faculty and students $(n=15)$, and technical support $(n=9)$.

Other resources that were mentioned less frequently included classroom microphones $(n=7)$, training $(n=7)$, good discussion board platforms $(n=7)$, reliable Internet connection $(n=4)$, a consistent institutional pedagogical approach $(n=3)$, open educational resources $(n=3)$, and teaching assistants $(n=2)$. Results of the responses to this open-ended question also drew attention to the fact that many participants lack knowledge of HyFlex learning and could not narrow down resources $(n=17)$. For example, some participants stated the following when asked which resources they felt were needed to successfully implement HyFlex learning opportunities at their institution: "I don't know what I would need as my experience is limited" and "don't know enough about it to answer." A few faculty members $(n=2)$ felt that they did not need any additional resources to successfully implement HyFlex learning opportunities at their institution. One faculty member responded: "None beyond what I already have." Table 5 shows various resource categories, the percentages of responses for each category, and example statements from survey participants.

\section{Table 5}

HyFlex Resources Categories, Percentages of Contributed Statements, and Representative Comments by Faculty Member

\begin{tabular}{|c|c|c|}
\hline Resources & Percentage & Example Statements \\
\hline $\begin{array}{l}\text { Synchronous and Asynchronous } \\
\text { Software }\end{array}$ & $27.54 \%$ & $\begin{array}{l}\text { "Access to video conferencing for individual/classroom } \\
\text { use and a good Webinar software platform (I cannot } \\
\text { recommend a particular tool for [institution], as I have not } \\
\text { done adequate research, nor do I have adequate familiarity } \\
\text { with the needs of other faculty). A good video capture } \\
\text { software application would also be very helpful (to support } \\
\text { non-synchronous preparatory work, class review, and/or } \\
\text { make up sessions for students who have an excused } \\
\text { absence). In addition, an online support tool (to support } \\
\text { virtual office hours as email/telephone can become } \\
\text { onerous (especially just prior to a due date) and is often an } \\
\text { inadequate way to respond to questions (especially if such } \\
\text { questions require problem mechanics or diagramming a } \\
\text { flowchart or similar). On that, a synchronous "e-white- } \\
\text { board" would be exceptionally helpful." }\end{array}$ \\
\hline $\begin{array}{l}\text { Lack of Knowledge/Cannot Narrow } \\
\text { Down Resources }\end{array}$ & $24.64 \%$ & "Not familiar with the resources required." \\
\hline Video Equipment in Classroom & $23.19 \%$ & $\begin{array}{l}\text { "It would help to have video equipment in classrooms to } \\
\text { allow online viewers to experience learning more as those } \\
\text { in the classroom do." }\end{array}$ \\
\hline $\begin{array}{l}\text { Reliable Equipment for Faculty and } \\
\text { Students }\end{array}$ & $21.74 \%$ & $\begin{array}{l}\text { "I'm more concerned about the quality of technology on } \\
\text { the students' end. Sometime the students have old devices } \\
\text { or unstable Internet connections, so their experience } \\
\text { suffers greatly compared to the others. Perhaps if all }\end{array}$ \\
\hline
\end{tabular}




\begin{tabular}{|c|c|c|}
\hline & & $\begin{array}{l}\text { enrolled students were given a standard machine to ensure } \\
\text { a baseline of quality across the classroom." }\end{array}$ \\
\hline $\begin{array}{l}\text { Technical Support for Faculty and } \\
\text { Students }\end{array}$ & $13.40 \%$ & "A 24/7 help desk for students and faculty." \\
\hline Classroom Microphones & $10.14 \%$ & $\begin{array}{l}\text { "Video-recording of the lectures. Or a microphone that } \\
\text { could pick up my voice as I walk around." }\end{array}$ \\
\hline Training & $10.14 \%$ & $\begin{array}{l}\text { "Paid training and rehearsals with knowledgeable others } \\
\text { would be optimal." }\end{array}$ \\
\hline Good Discussion Board Platforms & $10.14 \%$ & $\begin{array}{l}\text { "I find the most important tools necessary are great } \\
\text { discussion board platforms and high levels of } \\
\text { functionality. Definitely not Blackboard." }\end{array}$ \\
\hline Reliable Internet Connection & $5.80 \%$ & "Reliable connections to Internet" \\
\hline Consistent Institutional Approaches & $4.35 \%$ & $\begin{array}{l}\text { "A consistent approach/use/layout of the platform by all } \\
\text { faculty would help students adapt and become familiar in } \\
\text { its use....at least some sort of standardization within each } \\
\text { college." }\end{array}$ \\
\hline Open Educational Resources & $4.35 \%$ & $\begin{array}{l}\text { "Accessing free resources to augment the online } \\
\text { instructional experience." }\end{array}$ \\
\hline Teaching Assistants & $4.35 \%$ & $\begin{array}{l}\text { "Teaching assistants or student leads, depending on the } \\
\text { class size, to help meet student expectations." }\end{array}$ \\
\hline No Additional Resources Needed & $2.90 \%$ & "None beyond what I already have." \\
\hline
\end{tabular}

Participants were also invited, using an open-ended question, to share the types of support that they felt were needed to successfully implement HyFlex learning opportunities at their institution. Analysis of responses to this open-ended question $(n=76)$ revealed some overlap between the support and resources mentioned by participants. For example, direct instruction ( $n=39)$ using training, workshops, seminars, online tutorials, or webinars were welcome opportunities to support faculty wanting to implement HyFlex learning. Direct instruction in the form of training was also mentioned as a resource needed by faculty.

Other forms of support mentioned often included access to various educational technology software tools $(n=18)$ and a team of professionals $(n=16)$ which could include educational technologies, curriculum developers, instructional designers, and information technologists. Some participants also expressed interest in receiving support to implement HyFlex learning opportunities through a graduate student assistant $(n=14)$ or an experienced peer $(n=6)$. A few participants mentioned that they did not need any additional support $(n=5)$ or that they would need a course context to provide suggestions $(n=3)$. Table 6 shows the various support categories, the percentages of responses for each category, and example statements from survey participants. 


\section{Table 6}

HyFlex Support Categories, Percentages of Contributed Statements, and Representative Comments for Faculty Members

\begin{tabular}{|c|c|c|}
\hline Support & Percentage & Example Statements \\
\hline $\begin{array}{l}\text { Training, Workshops, Seminars, } \\
\text { Webinars }\end{array}$ & $59.22 \%$ & $\begin{array}{l}\text { "Courses, workdays, and seminars on teaching online } \\
\text { courses and pedagogical tools on how to teach online and } \\
\text { how to address specific areas, such as culture, diversity, } \\
\text { special needs, experiential learning activities through online } \\
\text { platform, etc." }\end{array}$ \\
\hline $\begin{array}{l}\text { Various Educational Technology } \\
\text { Tools }\end{array}$ & $23.68 \%$ & $\begin{array}{l}\text { "Use of a more fluid LMS. I find Blackboard to be bulky and } \\
\text { non-user friendly for students comparatively with other } \\
\text { platforms." }\end{array}$ \\
\hline $\begin{array}{l}\text { Educational Technologist/Course } \\
\text { Developer/Instructional } \\
\text { Designer/Tech Support Team }\end{array}$ & $21.05 \%$ & $\begin{array}{l}\text { "Need a dedicated staff/department for online support. This } \\
\text { is very common at other universities where I taught courses } \\
\text { completely online. The dedicated online staff is mandatory } \\
\text { for teaching online - otherwise, UT should not offer online } \\
\text { courses." }\end{array}$ \\
\hline $\begin{array}{l}\text { One-On-One Support/Graduate } \\
\text { Student Assistance }\end{array}$ & $18.42 \%$ & $\begin{array}{l}\text { "Course development assistance, Graduate assistants, } \\
\text { Curricular development assistance, and training to ensure } \\
\text { quality online is not different from quality in the classroom." }\end{array}$ \\
\hline $\begin{array}{l}\text { Experienced Professor's } \\
\text { Perspective }\end{array}$ & $7.89 \%$ & $\begin{array}{l}\text { "Someone that is familiar with Instructional design. I'm a } \\
\text { content expert, not an on-line delivery expert." }\end{array}$ \\
\hline Do Not Need Additional Support & $6.58 \%$ & $\begin{array}{l}\text { "To be honest I feel ready (I'm trained in instructional } \\
\text { technology). I have not taught online here at UT so I am not } \\
\text { aware of anything that can help us here at UT." }\end{array}$ \\
\hline Support Based on Course Context & $3.95 \%$ & "It all depends on what courses at what level (UG/GRAD)." \\
\hline
\end{tabular}

\section{Discussion}

This investigation provides insight about how faculty members teaching at institutions who do not currently use HyFlex instruction feel about the potential of integrating this type of online hybrid modality. Unlike other investigations on HyFlex instruction (Bell et al., 2014; Chakraborty \& Victor, 2004; Moore et al., 2017; Park \& Bonk, 2007; Popov, 2009; Roseth, Akcaoglu, \& Zellner, 2013; Ryu \& Boggs, 2016; Stewart et al., 2011; Szeto, 2015), this paper focuses on faculty preparedness prior to implementation.

The results indicate that faculty members feel prepared to engage in HyFlex instruction competencies that are similar to competencies required for other instructional formats such as inperson instruction. For example, instructors are prepared to communicate course goals and progress, make sure the learners feel comfortable in the instructional environment, and establish a presence. However, they admitted to feeling less prepared to manage the intricacies unique to the HyFlex modality. These intricacies involve equally managing students in two settings (inperson and online) during the same class period. Faculty seem less prepared to synchronously share content and their attention with the learners in the two different settings. 
In addition, faculty members report feeling moderately prepared to tackle critical aspects related to diversity, inclusion, and accessibility in the HyFlex instructional format. These results are on par with prior findings from previous literature. Several researchers have shared issues related to the attention and communication between instructor and students in the online environment in a HyFlex setting (Popov, 2009; Moore et al., 2017; Rogers et al., 2003). In this investigation, faculty members pro-actively shared that their preparedness for these competencies of HyFlex instruction is average, which can be a barrier for effective implementation but can also potentially encourage them to better prepare or seek additional professional development. These professional development opportunities could help create healthy design habits that are more inclusive of all learners (synchronous or asynchronous learners) such as pre-training learning activities and videos, instructor-learner pro-active communication before and after blended synchronous sessions, and equity of in class activities and assessments (Authors, 2017; Wang, Quek, \& Hu, 2017).

The results of the investigation highlight the variety of pedagogical approaches that instructors consider as they imagine their HyFlex classroom. Some faculty members thought about traditional asynchronous ways to engage with students in an online format such as the use of the Learning Management System (LMS), but others considered unique ways that would allow for synchronous collaboration, communication, and active learning using inquiry-based approaches, virtual surveys, and video sessions. These are similar to approaches shared in the existing literature (Roseth et al., 2013; Bell et al., 2014). It can also be deduced, based on the pedagogical approaches shared, that faculty members thought about strategies to engage learners outside a specified class session in an asynchronous format using discussion boards and prerecorded videos. Some of these pedagogical approaches were covered in the literature and implemented by faculty members who have previously designed and employed HyFlex instruction and aimed to a) create a balance of didactic approaches and b) make learners in both settings feel included (Wang et al., 2017).

In terms of resources and support, faculty members were very insightful and identified many assets, materials, supplies, measures, and staff that could aid them as they considered how to implement HyFlex instruction in their specific contexts. Many of the resources and support mentioned would intentionally address some of the major issues that, in the past, have prevented adequate implementation of the instruction: non-verbal communication in class (Stewart et al., 2011), poor communication among students and teachers (Popov, 2009; Moore et al., 2017), and inequalities that benefit online learners over in-person learners or vice-versa (Popov, 2009; Moore et al., 2017). The resources and support listed would also serve to provide feedback and ensure the highest quality of instruction given the limited knowledge of the HyFlex modality by the participants in this investigation.

\section{Significance of This Work}

The design of a HyFlex course requires that the instructor consider the structure, content, and activities for students in-person and online settings (Beatty, 2019). Giving careful attention to the design process will help ensure the course is well prepared to address the learning needs of HyFlex learners. The significance of this specific investigation is that it considers faculty preparedness before a decision to design a HyFlex course is even contemplated. Understanding their preparedness gives faculty ample time to explore opportunities for professional growth and development that they perhaps did not know were needed. 
This investigation is also significant because it provides organizational considerations related to infrastructure, resources, and support needed before implementation of HyFlex course offerings. It is critical that institutional leaders understand how various instructional modalities may require different or similar resources and support. In particular, institutional leaders need to assess the opportunities (benefits) and challenges (cost) of HyFlex. Many have stated that HyFlex can increase course offerings, provide flexibility to serve more students, increase enrollment, and build faculty capacity (Beatty, 2019). Yet, institutional leaders must also appreciate certain complexities and factors that can be costly prior to implementation, such as design support teams, classroom technology, and professional development resources. In addition to cost, many policies and procedures should be assessed to ensure adequate and positive learning experiences for both learners and faculty.

Research on HyFlex instruction is increasingly significant today as we consider alternative modalities that can provide access to learning experiences around the world and at different educational levels. The COVID-19 pandemic has fueled conversations about instructional modality as educational institutions and governments seek options to accommodate learners while maintaining safety. As Kelly (2020) stated in a blog post regarding hybrid-flexible course design during the pandemic, "the world (re)discovered HyFlex." However, given the newness of the HyFlex approach, administrators, faculty members, and learners face many questions about this instructional modality: what does the effective HyFlex design look like? Does it provide equal learning opportunities for all learners? Are students adequately prepared to learn in a HyFlex format? Have faculty members received sufficient professional development to truly embrace, design, and implement HyFlex instruction? Do adequate institutional resources and infrastructure exist to implement HyFlex?

The reality is this:

HyFlex does not have that extensive body of support research, but hundreds of institutions of all types are using HyFlex, and many of these institutions have been conducting initial studies of their own to test and revise their approaches and documenting the achievement of their unique set of HyFlex goals (Beatty, 2020). It is critical to research HyFlex instruction, as it serves to inform educational needs while we continue to deal with learning experiences at all educational levels during the COVID-19 pandemic.

\section{Limitations}

The findings of this study must be seen considering certain limitations. First, the considerations for implementation of HyFlex are evolving rapidly due to increased demand and necessities for application of this modality, especially during this COVID-19 pandemic. As researchers, we plan to re-survey the same faculty members to gather data on whether they have implemented HyFlex instruction since the COVID-19 pandemic started. It is very likely that some of the faculty members that participated in this investigation have since implemented HyFlex courses during the COVID-19 pandemic.

Another major limitation of this investigation is that all the participants belong to a specific educational institution. It is possible that the level of preparedness, pedagogical strategies, and resources and support needed are very different for faculty at other institutions of higher education depending on their enrollment, classification, administration, geographical location, and other factors. 
An additional constraint of this investigation and its findings is that the survey was distributed to all faculty members at this institution; however, not all faculty members have the same adeptness and inclination for online instruction. Conducting the same investigation with faculty who have a fondness and predisposition towards online teaching and learning could yield different results. Finally, this investigation was not focused on discipline-specific analysis of faculty preparedness for HyFlex instruction; instead, it aimed to provide an analysis of all faculty at a specific institution. Future research could concentrate on a more discipline-specific inquiry related to the implementation of HyFlex instruction.

\section{Conclusion}

The aim of this investigation was to survey faculty members on their perceived level of preparedness for teaching employing HyFlex instruction. Using an electronic survey, faculty members a) rated how prepared they were to engage on different competencies related to HyFlex instruction, b) shared which pedagogical strategies they felt prepared to use if given the opportunity to engage in HyFlex teaching, and c) listed the resources and support that they felt were needed to successfully implement this type of instructional format.

The HyFlex modality is an instructional format that researchers are starting to explore and better understand. Therefore, it is critical that we also investigate the level of faculty preparedness for HyFlex instruction. The results of this investigation highlight that, even with many years of experience teaching, the HyFlex instructional format is very new to faculty members. Overall, instructors feel prepared to teach in a HyFlex format, but certain competencies require further adjustment and improvement. Also, instructors believe a variety of pedagogical strategies can be integrated into HyFlex instruction. For those who are not familiar with this instructional format, however, significant support and resources are needed before designing and implementing a course.

\section{Acknowledgement}

This project was funded by an Undergraduate Research and Inquiry Grant [GR2965] from the University of Tampa. 


\section{References}

Angelone, L., Warner, Z., \& Zydney, J.M. (2020). Optimizing the technological design of a blended synchronous learning environment. Online Learning, 24(3), 222-240. https://doi.org/10.24059/olj.v24i3.2180

Beatty, B. J. (2019). Hybrid-flexible course design. https://edtechbooks.org/HyFlex

Beatty, B. (2020). Can HyFlex options support students in the midst of uncertainty? Transforming Higher Ed.https://er.educause.edu/blogs/2020/5/can-hyflex-optionssupport-students-in-the-midst-of-uncertainty

Bell, J., Sawaya, S., \& Cain, W. (2014). Synchromodal classes: Designing for shared learning experiences F2F and online students. International Journal of Designs for Learning, 5(1). https://doi.org/10.14434/ijdl.v5i1.12657

Bourdeau, D., Griffith, K., Griffith, J., \& Griffith, J. (2018). An investigation of the relationship between grades and learning mode in an English composition course. Journal of University Teaching \& Learning Practice, 15(2).

Chakraborty, M., \& Victor, S. (2004). Do's and don'ts of simultaneous instruction to on-campus and distance students via videoconferencing. Journal of Library Administration, 41(1-2), 97-112. https://doi.org/10.1300/J111v41n01_09

Creswell, J.W. (2009). Research design: Qualitative, quantitative, and mixed methods approaches. Sage.

Gruenhagen, K., Mccracken, T., \& True, J. (1999). Using distance education technologies for the supervision of student teachers in remote rural schools. Rural Special Education

Quarterly, 18(3-4), 58-65. https://doi.org/10.1177/8756870599018003-407

Irvine, V. (2020). The landscape of merging modalities. EDUCAUSE Review, 4, pp. 40-58. https://er.educause.edu/articles/2020/10/the-landscape-of-merging-modalities

Kelly, K. (2020, May 7). COVID-19 planning for fall 2020: A closer look at hybrid-flexible course design. Phil on EdTech. https://philonedtech.com/covid-19-planning-for-fall-2020-acloser-look-at-hybrid-flexible-course-design/

Martin, F. (2020). Examining faculty perception of their readiness to teach online. Online Learning, 23(3), p. 97-119.

Moore, M., Robinson, H., Sheffield, A., \& Phillips, A. (2017). Mastering the blend: A professional development program for K-12 teachers. Journal of Online Learning Research, $3(2)$.

Park, Y., \& Bonk, C. J. (2007). Is online life a breeze? A case study for promoting synchronous learning in a blended graduate course. MERLOT Journal of Online Learning and Teaching, 3(3). 
Popov, O. (2009). Teachers' and students' experiences of simultaneous teaching in an international distance and on-campus master's programme in engineering. The International Review of Research in Open and Distance Learning, 10(3).

Rogers, P., Graham, C., Rasmussen, R., Campbell, J., \& Ure, D. (2003). Blending face-to-face and distance learners in a synchronous class: Instructor and learner experiences. The Quarterly Review of Distance Education, 4(3).

Romero-Hall, E.J. \& Vicentini, C. (2017). Examining distance learners in hybrid synchronous instruction: Successes and challenges. Online Learning, 21(4), pp. 141-157.

http://dx.doi.org/10.24059/olj.v21i4.1258

Roseth, C., Akcaoglu, M., \& Zellner, A. (2013). Blending synchronous face-to-face and computer-supported cooperative learning in a hybrid doctoral seminar. TechTrends, 57(3), 54-59. https://doi.org/10.1007/s11528-013-0663-z

Ryu, J. \& Boggs, G. (2016). Teachers' perceptions about teaching multimodal composition: The case study of Korean English teachers at secondary schools. English Language Teaching, 9(6).

Stewart, A. R., Harlow, D. B., \& DeBacco, K. (2011). Students' experience of synchronous learning in distributed environments. Distance Education, 32(3), 357-381. https://doi.org/10.1080/01587919.2011.610289

Szeto, E. (2015). Community of Inquiry as an instructional approach: What effects of teaching, social and cognitive presences are there in blended synchronous learning and teaching? Computers \& Education, 81, 191-201. http://doi.org/10.1016/j.compedu.2014.10.015

Tesch, R. (1990). Qualitative research: Analysis types and software tools. Falmer Press.

Wang, Q., Quek, C., \& Hu, X. (2017). Designing and improving a blended synchronous learning environment: an educational design research. International Review of Research in Open and Distributed Learning, 18(3). 


\section{Appendix A}

\section{Faculty Preparedness for HyFlex Instruction}

Please specify your gender.

- Male

- Female

- Non-binary

- Prefer not to disclose

Which college at this institution are you primarily associated with?

- College of Arts and Letters

- College of Business

- College of Health and Natural Sciences

- College of Social Science, Mathematics, and Education

What is your highest degree?

- Doctoral degree

- Master's degree

- Bachelor's degree

What is your current academic rank at this institution?

- Tenured

- Tenure-Track

- Non-Tenure Track

Years of teaching experience?

- 0 to less than 1 year

- 1 to 5 years

- 6 to 10 years

- 11 to 15 years

- More than 15 years

Years of teaching in an online format?

- 0 to less than 1 year

- 1 to 5 years

- 6 to 10 years

- 11 to 15 years

- More than 15 years

Years of teaching in a synchronous online format?

- 0 to less than 1 year

- 1 to 5 years

- 6 to 10 years

- 11 to 15 years

- More than 15 years

Have you received any formal training related to the designing, developing, and/or implementing Internet-based distance education?

- Yes

- No 
The following statements will allow you to evaluate and reflect upon your competencies in key areas of synchronous online teaching. For each statement, please select the response that best represents you.

\begin{tabular}{|c|c|c|c|}
\hline \multirow{2}{*}{$\begin{array}{l}\text { Attend to the unique challenges of distance } \\
\text { learning where learners are separated by } \\
\text { time and geographic proximity. }\end{array}$} & I can do it very well & I can do it & I cannot do it \\
\hline & & & \\
\hline \multicolumn{4}{|l|}{$\begin{array}{l}\text { Attend to learning needs and situations of } \\
\text { both traditional age and adult learners, } \\
\text { providing a synchronous online educational } \\
\text { experience that is appropriate for both. }\end{array}$} \\
\hline \multicolumn{4}{|l|}{$\begin{array}{l}\text { Achieve mastery of the teaching and } \\
\text { learning in a synchronous online } \\
\text { environment by becoming familiar with all } \\
\text { materials, tools, and organization of the } \\
\text { course environment. }\end{array}$} \\
\hline \multicolumn{4}{|l|}{$\begin{array}{l}\text { Respond to in-person and online student's } \\
\text { inquiries via email or phone within } 12-24 \\
\text { hours to guide students towards a positive } \\
\text { learning outcome. }\end{array}$} \\
\hline \multicolumn{4}{|l|}{$\begin{array}{l}\text { Provide detailed feedback on assignments } \\
\text { and exams, in synchronous online format, } \\
\text { through facilitation, guidance, directed } \\
\text { learning, and progress assessment. }\end{array}$} \\
\hline \multicolumn{4}{|l|}{$\begin{array}{l}\text { Communicate as needed with in-person and } \\
\text { online students about course progress and } \\
\text { changes via email, course announcements, } \\
\text { etc. }\end{array}$} \\
\hline \multicolumn{4}{|l|}{$\begin{array}{l}\text { Encourage a safe, inviting, and mutually } \\
\text { respectful synchronous online environment } \\
\text { by communicating with students in a } \\
\text { positive tone and by promoting Netiquette } \\
\text { guidelines. }\end{array}$} \\
\hline \multicolumn{4}{|l|}{$\begin{array}{l}\text { Monitor and manage in-person and online } \\
\text { student progress by using course statistics } \\
\text { or reports to identify students who are not } \\
\text { accessing course materials or participating } \\
\text { in learning activities and reach out to } \\
\text { encourage engagement. }\end{array}$} \\
\hline \multicolumn{4}{|l|}{$\begin{array}{l}\text { Communicate course goals and outcomes } \\
\text { using the syllabus and course } \\
\text { announcements at the beginning of the } \\
\text { course, for both in-person and online } \\
\text { students }\end{array}$} \\
\hline \multicolumn{4}{|l|}{$\begin{array}{l}\text { Establish my presence, for both in-person } \\
\text { and online students, on a regular basis via } \\
\text { course announcements, assignments, } \\
\text { emails, online office hours, and various } \\
\text { other methods. }\end{array}$} \\
\hline $\begin{array}{l}\text { Throughout the synchronous online course, } \\
\text { demonstrate sensitivity to disabilities and } \\
\text { diversities, including aspects of cultural, } \\
\text { cognitive, emotional, and physical } \\
\text { differences. }\end{array}$ & & & \\
\hline
\end{tabular}




\section{Open-Ended Response Questions}

What pedagogical strategies are you familiar with and feel prepared to use for synchronous online teaching?

What additional support do you feel would help enhance your readiness to design and deliver synchronous online teaching experiences?

What additional resources (i.e., software, hardware, classroom facilities, etc.) would help your readiness to successfully implement synchronous online teaching experiences? 